\title{
Production and characterization of specific antibodies for evaluation of glycated insulin in plasma and biological tissues
}

\author{
A M McKillop, J T McCluskey, A C Boyd, M H Mooney, P R Flatt \\ and F P M O'Harte
}

School of Biomedical Sciences, University of Ulster, Cromore Road, Coleraine, Northern Ireland BT52 1SA

(Requests for offprints should be addressed to A McKillop; Email: am.mckillop@ulst.ac.uk)

\begin{abstract}
Previous studies have shown that glycation of insulin occurs in pancreatic $\beta$-cells under conditions of hyperglycaemia and that the site of glycation is the N-terminal $\mathrm{Phe}^{1}$ of the insulin B-chain. To enable evaluation of glycated insulin in diabetes, specific antibodies were raised in rabbits and guinea-pigs by using two synthetic peptides (A: Phe-Val-Asn-Gln-His-Leu-Cys-Tyr, and B: Phe-ValAsn-Gln-His-Leu-Tyr-Lys) modified by N-terminal glycation and corresponding closely to the N-terminal sequence of the glycated human insulin B-chain. For immunization, the glycated peptides were conjugated either to keyhole limpet haemocyanin or ovalbumin using glutaraldehyde, $m$-maleimidobenzoyl-N-hydroxysuccinimide ester or 1-ethyl-3-(3-dimethylamino propyl) carbodiimide hydrochloride. Antibody titration curves, obtained using $\mathrm{I}^{125}$-tyrosylated tracer prepared from glycated peptide A, revealed high-titre antisera in five groups of animals immunized for 8-28 weeks. The highest titres were observed in rabbits and guinea-pigs immunized with peptide B coupled to ovalbumin using glutaraldehyde. Under radioimmunoassay conditions, these antisera exhib-
\end{abstract}

ited effective dose (median) $\left(\mathrm{ED}_{50}\right)$ values for glycated insulin of $0 \cdot 3-15 \mathrm{ng} / \mathrm{ml}$ and $0.9-2.5 \mathrm{ng} / \mathrm{ml}$ respectively, with negligible cross-reactivity against insulin or other islet peptides. The degree of cross-reaction with glycated proinsulin was approximately 50\%. Glycated insulin in plasma of control and hydrocortisone-treated diabetic rats measured using rabbit 3 antiserum (1:10 000 dilution; sensitivity $<19 \mathrm{pg} / \mathrm{ml})$ was $0.08 \pm 0.01$ and $1.5 \pm 0.6 \mathrm{ng} /$ $\mathrm{ml}(P<0 \cdot 01)$, corresponding to 4 and $16 \%$ of total circulating insulin concentration respectively. Immunocytochemistry studies of the pancreas of streptozotocin-treated diabetic rats using a 1:1000 dilution of guinea-pig 2 antiserum revealed clusters of fluorescent positively stained cells in islets. These studies document the successful production of polyclonal antisera specific for glycated insulin and their usefulness in radioimmunoassays and immunocytochemistry. The demonstration of glycated insulin in plasma and islets of animal models of diabetes supports the view that glycation of insulin is involved in the pathogenesis of this disease.

Journal of Endocrinology (2000) 167, 153-163

\section{Introduction}

One of the major pathophysiological consequences of longterm elevation of plasma glucose in diabetes is an increase in the non-enzymatic glycation (glycosylation) of proteins (Brownlee 1995, Lyons \& Jenkins 1997, Brownlee 2000). The glycation process is initiated by nucleophilic addition of a reducing-sugar aldehyde group with an available amino group of amino acids, peptides or proteins. This non-enzymatic reaction is a reversible condensation reaction that produces an aldimine or labile Schiff base which dissociates readily or else undergoes rearrangement to form the more stable Amadori product; this eventually leads to the formation of irreversible advanced glycation end-products (AGEs) (Brownlee 1995).

The glycation of structural proteins, such as lens crystallins, has long been known to contribute to the development of many of the complications of diabetes (Perry et al. 1987). More recently, it has been established that glycation can disrupt normal cellular functions, including the activities of various enzymes such as $\mathrm{Cu}-\mathrm{Zn}$ superoxide dismutase, glucose-6-phosphate dehydrogenase and glutathione reductase (Blakytny \& Harding 1992, Oda et al. 1994, Ganea \& Harding 1994, Takahashi et al. 1995). Recent observations also suggest that glycation may contribute to the mechanisms through which hyperglycaemia exacerbates disturbances in pancreatic $\beta$-cell function and insulin action, which are the hallmark of glucose intolerance in type 2 diabetes (Unger \& Grundy 1985, Flatt et al. 1994, 1997).

Increasing evidence now exists to support the idea that insulin is glycated in the pancreatic $\beta$-cell under conditions of hyperglycaemia and that such structural modification contributes to insulin resistance by impairing insulin 
action (Lapolla et al. 1988, Flatt et al. 1997, Abdel-Wahab et al. 1997a). Thus, glycation of insulin and proinsulin has been shown to occur readily in the pancreata of normal and diabetic animal models (Abdel-Wahab et al. 1996, 1997b). Insulin is also rapidly glycated within, and secreted from, isolated pancreatic islets and clonal insulin-secreting cells maintained under hyperglycaemic conditions in tissue culture (Abdel-Wahab et al. 1996, 1997a). Studies have also shown that glycated insulin exhibits a reduced ability to regulate plasma glucose homeostasis in vivo and to stimulate adipose-tissue lipogenesis (Dolhofer \& Wieland 1979) or glucose uptake and oxidation by isolated diaphragm and abdominal muscle in vitro (Boyd et al. 1996, Abdel-Wahab et al. 1997b). When hyperinsulinaemic euglycaemic clamps were used in healthy human volunteers, glycated insulin was also shown to exhibit significantly impaired insulin-mediated glucose uptake (Boyd et al. 1996, Hunter et al. 1996).

Despite these various observations, technology to date has not been sensitive enough or reliable enough to measure circulating glycated insulin in normal or pathophysiological states. Since recent peptide chemistry studies have identified the site of glycation of human insulin to be the amino-terminal $\mathrm{Phe}^{1}$ of the B-chain (O'Harte et al. 1996), the present study was conducted in an attempt to raise polyclonal antibodies, of high affinity and specificity, to two glycated synthetic sequences from the insulin B-chain. This paper describes, for the first time, the successful production of polyclonal antisera specific for glycated insulin, the immunocytochemical demonstration of insulin in pancreatic islets and the development and use of a sensitive radioimmunoassay (RIA) for measuring glycated insulin in diabetic plasma.

\section{Materials and Methods}

\section{Reagents}

HPLC-grade acetonitrile was obtained from Rathburn (Walkersburn, UK). Sequencing-grade trifluoroacetic acid (TFA) was obtained from Aldrich (Poole, UK). Keyhole limpet haemocyanin (KLH: Megathura crenuiata) was obtained from Calbiochem (Nottingham, UK). All water used was purified using a Milli-Q water-purification system (Millipore, Milford, MA, USA). Glucose oxidase reagent was obtained from Beckman Instruments Ltd (Galway, Ireland). Dialysis tubing $\left(M_{\mathrm{r}} 2000\right.$ cut-off) was purchased from Spectra Medical Industries Inc. (Los Angeles, CA, USA). NaI ${ }^{125}(100 \mathrm{mCi} / \mathrm{ml})$ for iodination was obtained from Amersham International (Aylesbury, UK). Insulin-free serum was purchased from Biogenesis Ltd (Poole, UK). Peptide hormones were purchased from the American Peptide Company (Sunnyvale, CA, USA). All other chemicals, including glutaraldehyde (GLU), ovalbumin (OV), streptozotocin (STZ) and hydrocortisone, were of the highest quality available and were purchased from Sigma (Poole, UK).

\section{Animals}

Male New Zealand white rabbits $(n=12$, age 12 weeks) and Duncan Hartley guinea-pigs $(n=18,400-450 \mathrm{~g})$ were purchased from Laboratory Services, Queen's University, Belfast, UK. Male Wistar rats aged between 12 and 18 weeks were obtained for experimental studies from the Behaviourial and Biomedical Research Unit, University of Ulster, Coleraine. All animals were housed under controlled environmental conditions of temperature $\left(22 \pm 2{ }^{\circ} \mathrm{C}\right)$, relative humidity (45-65\%) and photoperiod (12 h light:12 h darkness). Pelleted diets for rabbits/ guinea-pigs or for rats (SDS Ltd, Witham, Essex, UK) were freely available as appropriate. Animals were also allowed to drink water ad libitum. Hyperglycaemia was induced in rats by intraperitoneal injections of hydrocortisone $(40 \mathrm{mg} / \mathrm{kg}$ body weight in $0 \cdot 2 \mathrm{ml}$ corn oil) twice daily for a period of 8 days. Control rats were injected twice daily with $0.2 \mathrm{ml}$ corn oil. Diabetes was also induced in rats by a single intraperitoneal injection of STZ (200 mg/ $\mathrm{kg}$ body weight) dissolved in $0.1 \mathrm{ml}$ of $0.1 \mathrm{~mol} / 1$ sodium citrate $(\mathrm{pH} 4 \cdot 5)$. These animals were maintained for a period of 14 days. Blood was collected from the tip of the tail into heparinized microcentrifuge tubes and the plasma separated (by centrifugation at $2500 \times \mathbf{g}$ for $10 \mathrm{~min}$ ) and stored at $-20{ }^{\circ} \mathrm{C}$ until analysis. All animal studies were performed in accordance with the Animals (Scientific Procedures) Act 1986.

\section{Preparation of synthetic insulin peptides}

Previous studies have established that insulin is naturally glycated at the N-terminal $\mathrm{Phe}^{1}$ of the insulin B-chain (O'Harte et al. 1996). For preparation of antibodies and an RIA specific for glycated insulin, two peptides that were closely related to the amino-terminal sequence of the insulin $\mathrm{B}$-chain $\left(\mathrm{Phe}^{1}-\mathrm{Val}^{2}-\mathrm{Asn}^{3}-\mathrm{Gln}^{4}-\mathrm{His}^{5}-\mathrm{Leu}^{6}-\mathrm{Cys}^{7}-\right.$ $\mathrm{Gly}^{8}{ }^{-}$) were synthesized. Peptide A comprised the naturally occurring $1-7$ sequence with the addition of a Tyr at position $8\left(\mathrm{Phe}^{1}-\mathrm{Val}^{2}-\mathrm{Asn}^{3}-\mathrm{Gln}^{4}-\mathrm{His}^{5}-\mathrm{Leu}^{6}-\mathrm{Cys}^{7}-\mathrm{Tyr}^{8}\right)$, whereas peptide $\mathrm{B}$ was extended from position 6 with a Tyr and a Lys at positions 7 and 8 respectively $\left(\mathrm{Phe}^{1}-\mathrm{Val}^{2}-\right.$ Asn ${ }^{3}-\mathrm{Gln}^{4}-\mathrm{His}^{5}-\mathrm{Leu}^{6}-\mathrm{Tyr}^{7}-\mathrm{Lys}^{8}$ ). Peptides were synthesized by Fmoc strategy and solid-phase peptide chemistry using a Applied Biosystems Synergy 432A peptide synthesizer (Foster City, CA, USA) starting from the Fmoc-Tyr-Wang and Fmoc-Lys-Wang resins respectively. After cleavage from the resin by TFA:water:thioanisole:ethanedithiol (90:2.5:5:2.5) (20 ml/g of resin), the peptide was removed by filtration and the filtrate volume was lowered under reduced pressure using a rotory evaporator. Diethyl ether was added slowly until a precipitate was observed. The precipitate was collected by low-speed centrifugation $(900 \times \mathbf{g}$ for $20 \mathrm{~min})$, resuspended in diethyl ether and centrifuged again, the procedure being carried out at least five times. The pellets were then dried 
Table 1 Immunization groups used in the production of antibodies against glycated insulin. Groups of three rabbits or guinea-pigs were immunized with either glycated insulin peptide A or glycated insulin peptide B linked to a carrier protein by a coupling agent. Animals received a primary immununization followed by booster injections at 4 -weekly intervals. At least six booster injections were given, with blood being taken 10 days after immunization. Antibody titres are expressed according to log-inverse transformation as means \pm S.E.M. of all bleeds (8-28 weeks) at 50\% binding, with the number of animals being given in parentheses

\begin{tabular}{|c|c|c|c|c|c|}
\hline & $\begin{array}{l}\text { Species } \\
(n=3)^{1}\end{array}$ & $\begin{array}{l}\text { Antigen } \\
\text { peptide }\end{array}$ & $\begin{array}{l}\text { Coupling } \\
\text { agent }^{2}\end{array}$ & $\begin{array}{l}\text { Carrier } \\
\text { protein }^{3}\end{array}$ & $\begin{array}{l}\text { Antibody titre } \\
\text { (log inverse) }\end{array}$ \\
\hline \multicolumn{6}{|c|}{ Group } \\
\hline 1 & GP & A & MBS & OV & - \\
\hline 2 & $\mathrm{R}$ & A & CDI & OV & $2 \cdot 98 \pm 0.08(15)$ \\
\hline 3 & $\mathrm{R}$ & A & MBS & KLH & - \\
\hline 4 & GP & A & MBS & $\mathrm{KLH}$ & - \\
\hline 5 & GP & A & CDI & $\mathrm{KLH}$ & - \\
\hline 6 & GP & B & GLU & OV & $3 \cdot 76 \pm 0 \cdot 06(18)$ \\
\hline 7 & $\mathrm{R}$ & B & GLU & OV & $4 \cdot 44 \pm 0 \cdot 10(18)$ \\
\hline 8 & GP & B & CDI & OV & $2 \cdot 64 \pm 0 \cdot 18(6)$ \\
\hline 9 & GP & B & GLU & $\mathrm{KLH}$ & - \\
\hline 10 & $\mathrm{R}$ & B & GLU & $\mathrm{KLH}$ & $1 \cdot 10 \pm 0 \cdot 03$ \\
\hline
\end{tabular}

in vacuo, cleaned up by reverse-phase high-performance liquid chromatography (RP-HPLC) on a Waters MILLENNIUM 2010 chromatography (software version $2 \cdot 1 \cdot 5$ ) and molecular identity was confirmed as described below using a high-resolution LCQ ion-trap mass spectrometer (Finnigan MAT, San Jose, CA, USA). The SWISSPROT and SWISSPROTNEW databases did not reveal any known peptides or proteins containing sequences similar to peptides $\mathrm{A}$ and $\mathrm{B}$, other than insulin and proinsulin.

\section{Preparation and purification of glycated insulin peptides}

Synthetic insulin peptides A and B were stably glycated by exposure to D-glucose $(220 \mathrm{mmol} / \mathrm{l})$ for $24 \mathrm{~h}$ at $37^{\circ} \mathrm{C}$ in the presence of the reducing agent sodium cyanoborohydride, as previously described (O'Harte et al. 1996). Glycated and non-glycated peptides were separated by RP-HPLC (O'Harte et al. 1996) using a Vydac (C-18) 218TP54 $(4.6 \times 250 \mathrm{~mm})$ analytical column (The Separations Group, Hesperia, CA, USA) at a flow rate of $1 \cdot 0 \mathrm{ml} / \mathrm{min}$. The mobile phase consisted of solvent A $(0.12 \%(\mathrm{v} / \mathrm{v})$ TFA in water) and solvent B $(0 \cdot 1 \%(\mathrm{v} / \mathrm{v})$ TFA in $70 \%$ acetonitrile $/ 29.9 \%$ water). A linear gradient of $0-20 \%(\mathrm{v} / \mathrm{v})$ acetonitrile over $10 \mathrm{~min}$ was used; this was followed by a gradient of $20-60 \%(\mathrm{v} / \mathrm{v})$ acetonitrile over $30 \mathrm{~min}$. Elution profiles were monitored at $206 \mathrm{~nm}$ and peptide peaks collected manually. Pooled glycated peptide fractions were concentrated under vacuum using an AES 1000 Speed Vac Concentrator (Life Sciences International, Runcorn, UK).
Confirmation of structure by electrospray ionization-mass spectrometry

Glycated and non-glycated peptides were identified by electrospray ionization/mass spectrometry (ESI-MS). The peptides were dissolved in $0.12 \%(\mathrm{v} / \mathrm{v})$ TFA in water and applied at a flow rate of $10 \mu \mathrm{l} / \mathrm{min}$ by syringe injection to the electrospray ionization source of an LCQ ion-trap mass spectrometer (Finnigan MAT). Spectra were obtained from a quadrupole ion-trap mass analyser. The mass range of the detector was $m / z 150-2000$. For direct injection, the interface to the mass spectrometer was operated with the heated capillary at a temperature of $220{ }^{\circ} \mathrm{C}$. The molecular masses of glycated and native peptides were determined using prominent multiple charged ions and the equation $M_{\mathrm{r}}=i M_{\mathrm{i}}-M_{\mathrm{h}}$, where $M_{\mathrm{r}}$ is molecular mass, $M_{\mathrm{i}}$ is the $m / z$ ratio, $i$ is the number of charges, and $M_{\mathrm{h}}$ is the mass of a proton.

\section{Preparation of immunogen}

Ten groups each containing three rabbits or guinea-pigs were immunized with either glycated peptide A or glycated peptide B linked to two different carrier proteins (KLH or OV) using a range of conjugation agents (Table 1). Glycated peptide A was linked to the carrier protein via a $\mathrm{Cys}^{7}$ side chain (using the $m$-maleimidobenzoyl$\mathrm{N}$-hydroxysuccinimide ester, MBS) or the terminal carboxylic group (using 1-ethyl-3-(3-dimethylaminopropyl) carbodiimide hydrochloride, CDI). Glycated peptide B 
was linked to the carrier protein via the $\varepsilon$-amino group of Lys (using GLU) or the terminal carboxylic group (using CDI). Correct orientation and coupling of the carrier protein to the C-terminus of the glycated peptides were critical, and overcoupling was limited by the amount of linker used.

Coupling of glycated insulin to carrier proteins using glutaraldehyde

Carrier protein $(0 \cdot 1 \mu \mathrm{mol}, 45 \mathrm{mg} \mathrm{KLH}$ or $4.5 \mathrm{mg} \mathrm{OV})$ was added to glycated insulin peptide B $(4 \mathrm{mg} / \mathrm{ml}$ in PBS) at the correct molar ratio (approximately 1 mole peptide per 50 amino acids of carrier) and stirred for $2 \mathrm{~h}$ at $25^{\circ} \mathrm{C}$ (Harlow \& Lane 1988). An equal volume of freshly prepared $0 \cdot 2 \%$ GLU in PBS was added dropwise to the peptide/carrier protein solution and incubated with constant agitation for $1 \mathrm{~h}$ at $25^{\circ} \mathrm{C}$. Excessive cross-linking of GLU was indicated by the insolubility of KLH. The peptide solution was incubated for $1 \mathrm{~h}$ following the addition of $1 \mathrm{M}$ glycine/PBS (pH 7.2) (final concentration $0 \cdot 2 \mathrm{~mol} / \mathrm{l})$ to quench unreacted aldehyde. The peptide/ carrier protein conjugate was separated from free peptide by dialysis with three changes of PBS overnight at $4{ }^{\circ} \mathrm{C}$.

\section{Coupling of glycated insulin to carrier proteins using MBS}

As MBS can link peptides to carrier proteins through cysteines and free amino groups, glycated insulin peptide A was initially treated with citraconic anhydride to block free amino groups in the peptide. An equal volume of citraconic anhydride $(10 \mathrm{mg} / \mathrm{ml})$ was added to glycated insulin peptide $\mathrm{A}(10 \mathrm{mg} / \mathrm{ml}, \mathrm{pH} 8 \cdot 5)$. The $\mathrm{pH}$ was monitored and kept between 8 and 9. The solution was incubated for $1 \mathrm{~h}$ at $25^{\circ} \mathrm{C}$; this was followed by the addition of $0 \cdot 1$ volume of $1 \mathrm{~mol} / 1$ sodium phosphate $(\mathrm{pH}$ $7 \cdot 2$ ). MBS in dimethylformamide (final concentration $3 \mathrm{mg} / \mathrm{ml}$ ) was added to the peptide solution and incubated with agitation for $30 \mathrm{~min}$ at $25^{\circ} \mathrm{C}$. To remove any remaining maleimide, mercaptoethanol (final concentration $35 \mathrm{mmol} / \mathrm{l}$ ) was added and incubated for $1 \mathrm{~h}$ at $25{ }^{\circ} \mathrm{C}$. Sufficient carrier protein $(0.25 \mu \mathrm{mol}, 112.5 \mathrm{mg}$ $\mathrm{KLH}$ or $11.3 \mathrm{mg} \mathrm{OV}$ ) was added to the activated peptide to obtain a final ratio of approximately 1 mole of peptide for every 50 amino acids of carrier protein (Harlow \& Lane 1988). The peptide/protein conjugate was incubated for $3 \mathrm{~h}$ and dialysed against PBS overnight to remove uncoupled peptide.

\section{Coupling of glycated peptide to carrier proteins using carbodiimide}

To stop the cross-linking of one peptide to another, an equal volume of citraconic anhydride $(10 \mathrm{mg} / \mathrm{ml})$ was added to glycated insulin peptides A and B $(10 \mathrm{mg} / \mathrm{ml}, \mathrm{pH}$ $8 \cdot 5)$ and the solution incubated for $1 \mathrm{~h}$ at $25^{\circ} \mathrm{C}$. The peptide was diluted to $1 \mathrm{mg} / \mathrm{ml}$, and, following the addition of CDI (final concentration $10 \mathrm{mg} / \mathrm{ml}$ ), the solution was incubated for $5 \mathrm{~min}$ at $25^{\circ} \mathrm{C}$. An equal volume of carrier protein $(0.25 \mu \mathrm{mol}, 112.5 \mathrm{mg} \mathrm{KLH}$ or $11.3 \mathrm{mg} \mathrm{OV}$ ) was added to yield a molar ratio of approximately 1 mole peptide to 50 amino acids of protein (Harlow \& Lowe 1988). The conjugate was incubated for $4 \mathrm{~h}$ at $25{ }^{\circ} \mathrm{C}$ and the reaction was stopped with $100 \mathrm{mmol} / 1$ sodium acetate ( $\mathrm{pH} \mathrm{4 \cdot 2)}$ and then incubated for a further hour. Uncoupled peptide was removed by dialysis against sodium acetate $(\mathrm{pH} 4 \cdot 2)$ for $3 \mathrm{~h}$ and then against PBS overnight at $4{ }^{\circ} \mathrm{C}$.

\section{Immunization procedure}

Rabbits and guinea-pigs were injected at multiple (5-7) subcutaneous sites with conjugate (Table 1) in an emulsion formed with equal volumes of Freund's adjuvant (1-2 ml/ animal) prepared immediately before injection. A preimmune sample was taken. Rabbits $(n=3)$ and guinea-pigs $(n=3)$ were given 0.5 and $0.3 \mathrm{mg}$ immunogen at primary immunizations and then 0.17 and $0.1 \mathrm{mg}$ respectively for subsequent booster injections at 4-week intervals. All animals received at least six boosters and blood samples were taken 10 days after immunization. Blood was stored at $4{ }^{\circ} \mathrm{C}$ overnight and the serum separated after centrifugation $(2500 \times \mathbf{g}$ for $10 \mathrm{~min})$, aliquoted and then stored at $-20{ }^{\circ} \mathrm{C}$.

\section{Preparation of iodinated tracer}

A high-specific-activity mono-iodinated $\mathrm{I}^{125}$-tyrosylated glycated peptide tracer was prepared from glycated insulin peptide A using the solid-phase iodogen method (Salacinski et al. 1981). Iodinated peptide was purified by RP-HPLC, using a Vydac (C-8) $(4.6 \times 250 \mathrm{~mm})$ analytical column at a flow rate of $1.0 \mathrm{ml} / \mathrm{min}$. A linear gradient of $0-42 \%$ acetonitrile over $40 \mathrm{~min}$ was used. Fractions corresponding to the mono-iodinated glycated peptide tracer were pooled, aliquoted and then stored at $4{ }^{\circ} \mathrm{C}$.

\section{Evaluation of antisera by radioimmunoassay}

Antisera to glycated insulin peptides were screened by dextran-coated charcoal RIA based on the method described by Flatt \& Bailey (1981). Antibody dilution curves were constructed in $40 \mathrm{mmol} / 1$ sodium phosphate buffer $\left(5 \mathrm{mg} / \mathrm{ml} \mathrm{BSA}\right.$; pH 7.4) by incubating (for $48 \mathrm{~h}$ at $4{ }^{\circ} \mathrm{C}$ ) $\mathrm{I}^{125}$-glycated peptide tracer (approx. 10000 c.p.m./ $100 \mu \mathrm{l})$ with each of the antisera at final dilutions of $1: 10$, 1:100, 1:1000, 1:2000, 1:5000, 1:10 000 and 1:50 000. To evaluate the affinity and specificity of the antisera, standard curves were prepared using $100 \mu \mathrm{I} \mathrm{I}^{125}$-glycated peptide tracer, $100 \mu \mathrm{l}$ antisera, $100 \mu \mathrm{l}$ of $40 \mathrm{mmol} / 1$ sodium phosphate buffer and $100 \mu \mathrm{l}$ insulin or $100 \mu \mathrm{l}$ glycated 
insulin standards (range 0.019-40 ng/ml). The $48 \mathrm{~h}$ incubation period was preceded by $24 \mathrm{~h}$ of incubation prior to addition of tracer. The cross-reactivity of antisera with other hormones $(10 \mathrm{mg} / \mathrm{ml})$ was determined with insulin, proinsulin, glycated proinsulin, glucagon, somatostatin, C-peptide, and advanced glycation endproduct-BSA (AGE-BSA). Glycated insulin and proinsulin were prepared and quantified as described previously (O'Harte et al. 1996). AGE-BSA was prepared by incubating BSA $(1 \mathrm{mg} / \mathrm{ml})$ with $\mathrm{D}$-glucose $(220 \mathrm{mmol} / \mathrm{l})$ in the presence of sodium cyanoborohydride for 6 weeks at $37^{\circ} \mathrm{C}$. For blood assays, the glycated insulin standard curve was constructed in the presence of immunostripped human insulin-free serum obtained from Biogenesis Ltd.

\section{Immunocytochemistry}

Pancreatic tissue from rats with STZ-induced diabetes (plasma glucose $>15 \mathrm{mmol} / \mathrm{l}$ ) and controls (no treatment, plasma glucose $2.5 \mathrm{mmol} / \mathrm{l}$ ) was fixed in $4 \%$ paraformaldehyde/PBS, embedded in paraffin and sections cut at $7 \mu \mathrm{m}$. After permeabilization in $0 \cdot 3 \%$ Triton X-100 and blocking in normal goat serum (Vector Laboratories, Burlingame, CA, USA), tissue sections were incubated in primary antibody for $1 \mathrm{~h}$, then incubated for $45 \mathrm{~min}$ with a fluorescein isothiocyanate (FITC)-labelled secondary antibody (1:40 dilution, goat anti-rabbit; Vector Laboratories). All steps were carried out at $25{ }^{\circ} \mathrm{C}$. Stained sections were visualized using an FITC-filter on an Optiphot 2 microscope (Nikon, Chiyoda-ku, Tokyo, Japan) and the images digitally recorded using the IMAGEDOK program (Kinetic Imaging Ltd, Liverpool, UK).

\section{Glucose and insulin assays}

Glucose concentrations were measured by an automated glucose oxidase method (Stevens 1971) using a Beckman Glucose Analyzer 2 (Beckman Instruments Ltd). Insulin concentrations were determined by dextran-coated charcoal RIA using cross-reacting guinea-pig antiporcine insulin antiserum, $\mathrm{I}^{125}$-bovine insulin tracer and a rat-insulin standard as described previously (Flatt \& Bailey 1981). This antibody does not discriminate between glycated and native insulin (Abdel-Wahab et al. 1997a).

\section{Statistical analysis}

All experimental data are expressed as means \pm s.E.M. Significant differences between groups of data were assessed using the unpaired Student's $t$-test and statistical significance was assumed for $P<0 \cdot 05$.

\section{Results}

\section{Purification of glycated peptide epitopes}

Two synthetic insulin peptides (A, $M_{\mathrm{r}} 1022.5 ; \mathrm{B}, M_{\mathrm{r}}$ 1047.5) were stably glycated under hyperglycaemic reducing conditions and purified by RP-HPLC. The primary structures of the glycated peptides were confirmed by ESI-MS (Fig. 1). Prominent multiply charged species $(\mathrm{M}+\mathrm{H})^{1+}$ and $(\mathrm{M}+\mathrm{H})^{2+}$ were detected for glycated insulin peptide $A$ at $m / z$ values of $1187 \cdot 3$ and 594.3 respectively, corresponding to an intact molecular mass of $1186 \cdot 3 \mathrm{Da}$ (theoretical $\left.M_{\mathrm{r}} 1186 \cdot 2\right)$. The multiple charged species $(\mathrm{M}+\mathrm{H})^{1+}$ and $(\mathrm{M}+\mathrm{H})^{2+}$ were obtained for glycated insulin peptide $\mathrm{B}$ at $\mathrm{m} / z$ values of 1212.5 and 606.9 and corresponded to a molecular mass of $1211.5 \mathrm{Da}$ (theoretical $\left.M_{\mathrm{r}} 1211 \cdot 2\right)$. The difference between the $M_{\mathrm{r}}$ values of the glycated and non-glycated peptides (164.1 and $164 \cdot 0)$ corresponded exactly to the addition of a single glucitol adduct (theoretical $M_{\mathrm{r}} 164$ ).

\section{Antibody production}

Guinea-pigs (GP) and rabbits (R) were immunized with a number of combinations of glycated insulin peptide (A or $\mathrm{B})$, linker (MBS, CDI or GLU) and carrier protein (OV or KLH) (Table 1). Serum samples obtained 10 days after each monthly booster were screened by RIA using mono-iodinated glycated insulin peptide A tracer purified by HPLC (Fig. 2). There was no evidence of any binding of tracer to pre-immune sera. Five out of the 10 immunized groups of animals developed antibodies against glycated insulin (Table 1). The unsuccessful combinations included group 1 (GP/A/MBS/OV), group 3 (R/A/MBS/KLH), group 4 (GP/A/MBS/KLH), group $5(\mathrm{GP} / \mathrm{A} / \mathrm{CDI} / \mathrm{KLH})$ and group $9(\mathrm{GP} / \mathrm{B} / \mathrm{GLU} /$ $\mathrm{KLH})$.

The construction of antibody titration curves showed that all three animals in group $2(\mathrm{R} / \mathrm{A} / \mathrm{CDI} / \mathrm{OV})$, group $6(\mathrm{GP} / \mathrm{B} / \mathrm{GLU} / \mathrm{OV})$ and group 7 (R/B/GLU/OV) generated high-titre antibodies (Figs 3 and 4). One guinea-pig from group $8(\mathrm{GP} / \mathrm{B} / \mathrm{CDI} / \mathrm{OV})$ also responded reasonably well (Fig. 4). Group 10 (R/B/GLU/KLH) contained one rabbit that yielded low-titre antibodies (data not shown). Antibodies in the four successful groups of guinea-pigs and rabbits were evident at 8 weeks, and 50\% maximum binding titres tended to increase over the 28 -week period (Figs 3 and 4). As shown in Table 1, mean titres \pm S.E.M. (expressed as log-inverse transforms) for groups 2, 6, 7 and 8 were $2.98 \pm 0.08 \quad(n=15), 3.76 \pm 0.06 \quad(n=18)$, $4 \cdot 44 \pm 0 \cdot 10 \quad(n=18)$ and $2 \cdot 64 \pm 0 \cdot 18 \quad(n=6)$. The single rabbit in group 10 had antibody titres of $1.10 \pm 0.03$ $(n=4)$. Comparison of titres by Student's $t$-test revealed the order group $7>$ group $6>$ group $2>$ group $8>$ group 10 . The most successful immunogen in rabbits (group 7) and guinea-pigs (group 6) was peptide B coupled to OV using GLU. Peptides A (group 2) or B (group 8) coupled to OV with CDI appeared to be the next most effective. KLH was weakly immunogenic coupled to peptide B using GLU (group 10), whereas the two groups with MBS as the coupling agent failed to generate antibodies. 

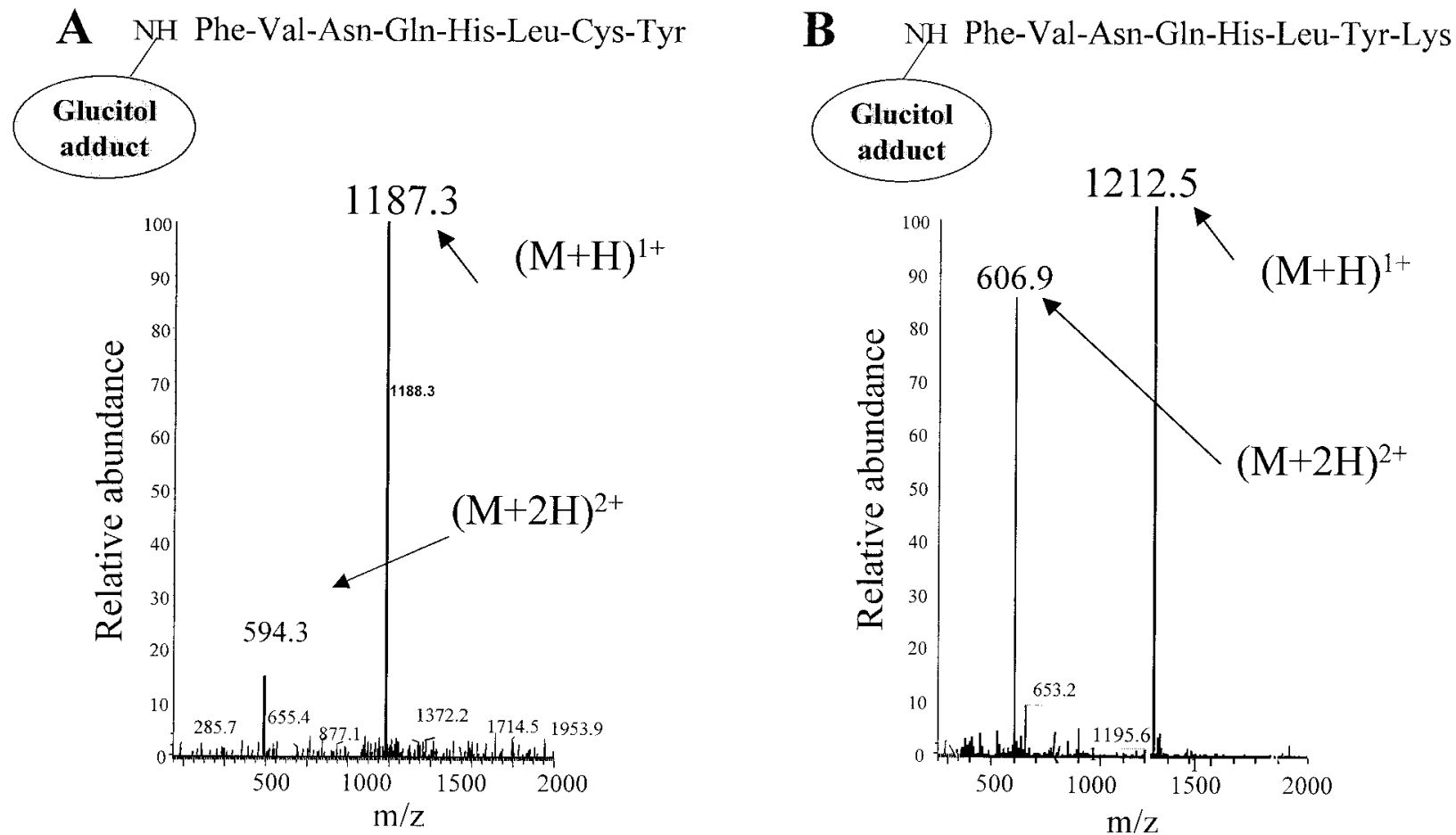

Figure 1 ESI-MS of $(A)$ glycated insulin peptide $A\left(M_{r} 1186 \cdot 3\right)$ and $(B)$ glycated insulin peptide $B\left(M_{r} 1211 \cdot 5\right)$. Peptides were dissolved in $0 \cdot 1 \%$ TFA in water and applied by direct syringe injection to an ESI-MS at a flow rate of $0.01 \mathrm{ml} / \mathrm{min}$ in $35 \%$ acetonitrile/water. Spectra were collected using full-ion scan mode over the $m / z$ ratio of $150-2000$ and the $M_{\mathrm{r}}$ was determined using the equation $M_{\mathrm{r}}=i M_{\mathrm{i}}-i M_{\mathrm{h}}$ (see Materials and Methods section).

\section{Sensitivity and specificity of antibodies}

The reactivity of antisera from high-titre groups 6 and 7 with insulin and glycated insulin was determined using

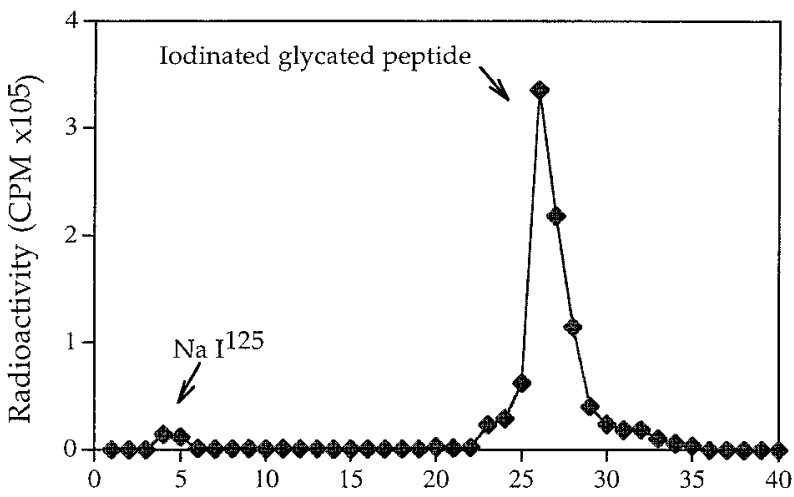

Fraction Number

Figure 2 Purification of iodinated glycated insulin peptide A by RP-HPLC. The ${ }^{125}$ I-labelled peptide was prepared by the solid-phase iodogen method and purified by RP-HPLC using a Vydac $(C-8)(4.6 \times 250 \mathrm{~mm})$ analytical column, with a linear gradient of $0-42 \%$ acetonitrile at a flow rate of $1.0 \mathrm{ml} / \mathrm{min}$. The peak fraction containing the mono-iodinated glycated peptide tracer was used for RIA. binding displacement curves over a range of peptide concentrations $\left(0 \cdot 019-10 \mathrm{ng} / \mathrm{ml}\right.$ ). The index $\mathrm{B} / \mathrm{B}_{0}$ (where $\mathrm{B}_{0}$ and $\mathrm{B}$ represent counts bound to antibody in the absence and presence of glycated or native insulin respectively) allowed evaluation of displacement. The $\mathrm{ED}_{50}$ values for glycated insulin for guinea-pigs 1-3 in group 6 (final bleed; number vi) were 2.5, 1.25 and $0.9 \mathrm{ng} / \mathrm{ml}$, respectively (Fig. 5). No cross-reactivity was found with human insulin over the range of concentrations. $\mathrm{ED}_{50}$ values for rabbits $1-3$ in group 7 (final bleed; number vi) were $15,9.6$ and $0.3 \mathrm{ng} / \mathrm{ml}$ respectively, with no displacement by human insulin (Fig. 6). The assay using bleed vi from rabbit 3 had a sensitivity of $<19 \mathrm{pg} / \mathrm{ml}$, an intra-assay precision of $8 \cdot 7 \%$ (coefficient of variance, $\mathrm{CV}$ ). CVs for standard curve parameters $(\leq 2.5 \mathrm{ng} / \mathrm{ml})$ were in the range $12-22 \%$. The antisera from these guinea-pigs or rabbits did not cross-react $(<0 \cdot 001 \%)$ with other islet hormones $(10 \mathrm{ng} / \mathrm{ml})$, including proinsulin, C-peptide, glucagon, somatostatin or AGE-BSA, but there was $52-56 \%$ cross-reactivity with glycated proinsulin (data not shown). Antiserum from rabbit 3 (group 7: R3/B/GLU/OV/vi) was selected to assess glycated insulin in biological samples. This antiserum was used at a dilution of 1:10 000 in RIA (log-inverse titre $4 \cdot 0)$ and the standard curve was free from serum effects as assessed using insulin-free serum (data not shown). 

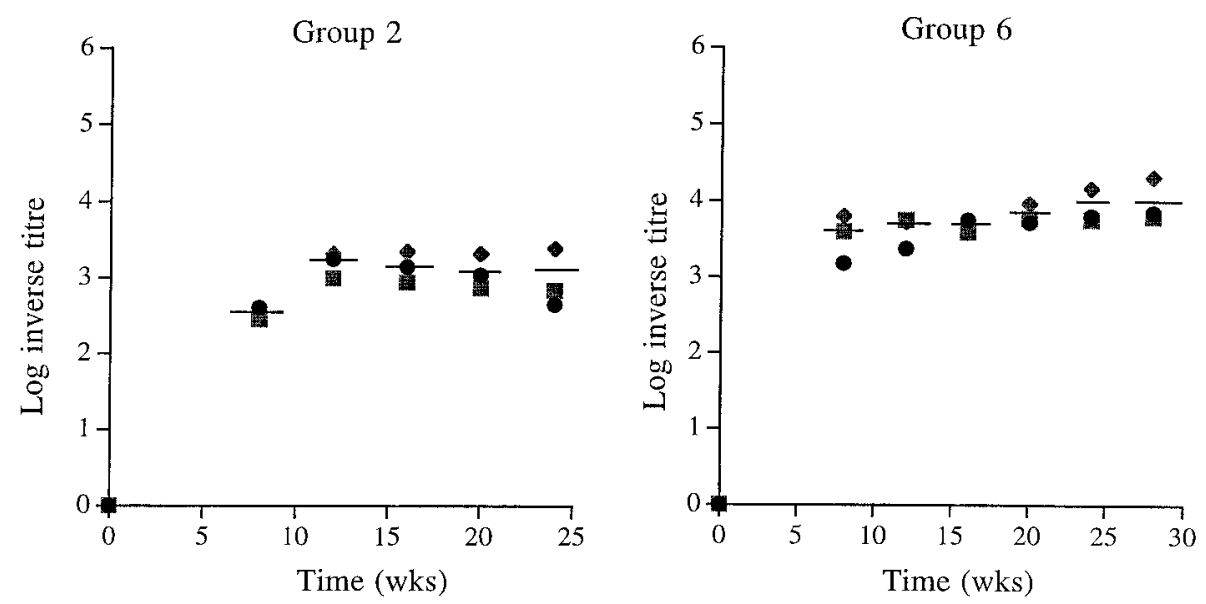

Figure 3 Antisera evaluation of rabbits in group 2 (R/A/CDI/OV) and guinea-pigs in group 6 (GP/B/GLU/OV). The logarithm of the inverse final working dilution of the antiserum that will bind $50 \%$ of the label was determined by antibody titration curves. Mean values are shown for animals 1 $(\bullet), 2(\checkmark)$ and $3(\square)$, the overall mean of the group being shown by a horizontal bar.
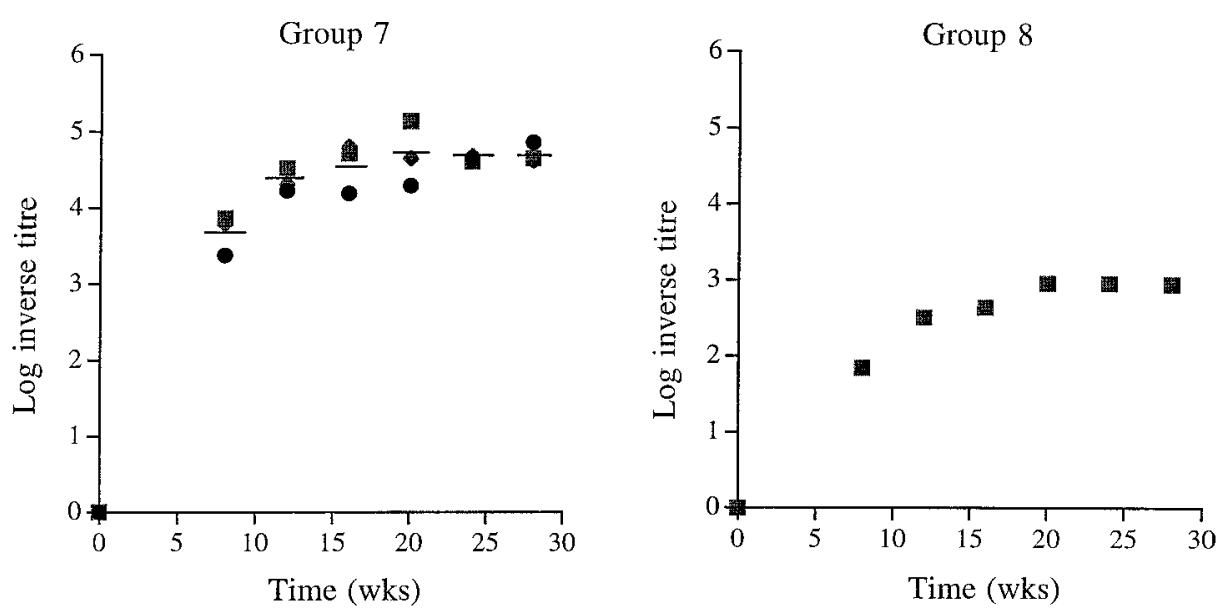

Figure 4 Antisera evaluation of rabbits in group 7 (R/B/GLU/OV) and guinea-pigs in group 8 $(\mathrm{GP} / \mathrm{B} / \mathrm{CDI} / \mathrm{OV})$. The logarithm of the inverse final working dilution of the antiserum that will bind $50 \%$ of the label was determined by antibody titration curves. Mean values are shown for animal 1

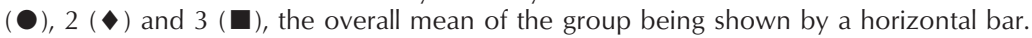

\section{Detection of glycated insulin in plasma and islets in diabetes}

Hydrocortisone-treated rats exhibited hyperglycaemia and hyperinsulinaemia, indicative of a severe state of insulin resistance (Fig. 7). Glycated insulin was readily detectable by RIA in plasma from control and hydrocortisone-treated rats. The circulating concentration in control animals was $0 \cdot 08 \pm 0 \cdot 01 \mathrm{ng} / \mathrm{ml}(n=4)$, representing about $4 \%$ of total plasma insulin measured using a cross-reacting insulin antibody (Fig. 7). The concentration of glycated insulin in plasma from hydrocortisone-treated rats was elevated 19-fold $(P<0.01)$, corresponding to $1.5 \pm 0.6 \mathrm{ng} / \mathrm{ml}$ $(n=4)$. As shown in Fig. 7, glycated insulin represented approximately $16 \%$ of total plasma insulin in the hydro- cortisone-treated diabetic rats $(P<0 \cdot 01$ compared with controls).

\section{Immunocytochemical studies}

Immunocytochemical studies were performed using pancreatic tissue sections derived from rats with STZinduced diabetes and non-diabetic control rats, using FITC-labelled secondary antibody. These studies were performed using a 1:1000 dilution of antiserum from guinea-pig 2, group 6 (GP2/B/GLU/OV/vi). Figure 8A illustrates clusters of fluorescent positively stained cells in a diabetic islet, with surrounding non-stained exocrine cells. 

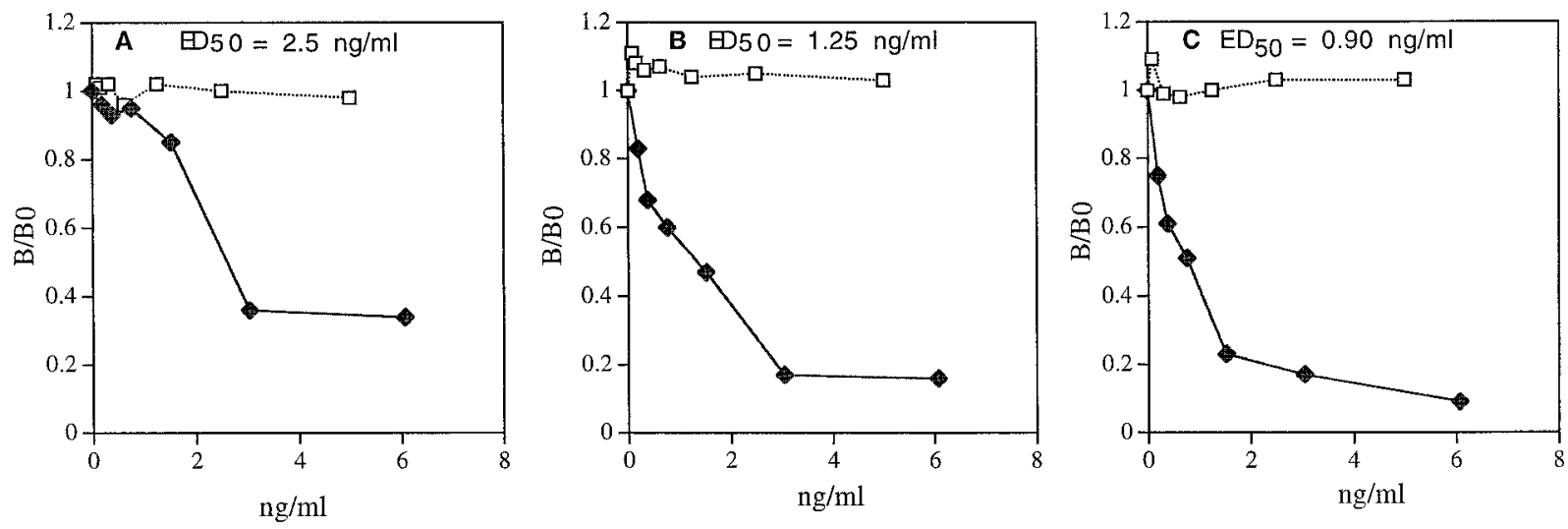

Figure 5 Cross-reactivity of antisera from guinea-pigs 1-3 (A-C) from group $6(\mathrm{GP} / \mathrm{B} / \mathrm{GLU} / \mathrm{OV})$ with glycated insulin ( ) and insulin ( $\square$ ). Results are expressed as an index given by the equation $100 \times B_{0}-B / B_{0}$, where $B_{0}$ and $B$ represent counts bound to antibody in the absence and presence of glycated or native insulin respectively.
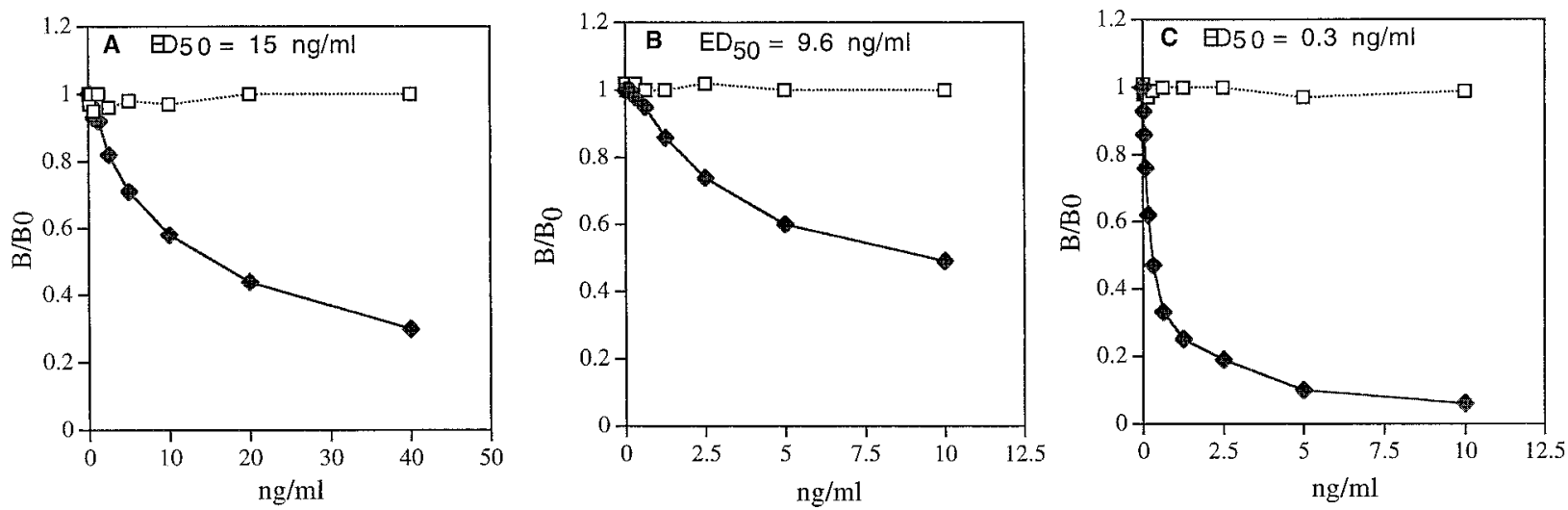

Figure 6 Cross-reactivity of antisera from rabbits 1-3 (A-C) from group 7 (R/B/GLU/OV) with glycated insulin ( ) and insulin ( $\square$ ). Results are expressed as an index given by the equation $100 \times B_{0}-B / B_{0}$, where $B_{0}$ and $B$ represent counts bound to antibody in the absence and presence of glycated or native insulin respectively.

The islets of control rats also contained numerous positive cells but these were less intensely stained by the glycated insulin antibody (Fig. 8B).

\section{Discussion}

It is now 15 years since it was first proposed that hyperglycaemia could be an inducer as well as consequence of pancreatic $\beta$-cell dysfunction and insulin resistance (Unger \& Grundy 1985). The concept of glucose toxicity is now a well-recognized phenomenon (Flatt et al. 1997, Lyons \& Jenkins 1997), and considerable effort has been devoted, in particular, to understanding the mechanisms by which elevated glucose concentrations cause $\beta$-cell dysfunction and impaired insulin secretion in type 2 diabetes (Lapolla et al. 1988, Boyd et al. 1996, Abdel-Wahab et al. 1997b, Flatt et al. 1997). As part of this effort, we have explored the possible involvement of glycation of functional $\beta$-cell proteins (Flatt et al. 1994, 1997), demonstrating that both proinsulin and insulin can be glycated within the $\beta$-cells during the stages of biosynthesis and storage (AbdelWahab et al. 1996, 1997a).

Evidence for the glycation of $\beta$-cell proteins includes the demonstration of glycated insulin in pancreatic extracts from various animal models of diabetes (Abdel-Wahab et al. 1996) and the time- and concentration-dependent glycation of insulin in both isolated mouse islets and clonal insulin-secreting cell lines under hyperglycaemic culture (Abdel-Wahab et al. 1996, 1997a). Thus the milieu within the pancreatic $\beta$-cells appears to represent a particularly favourable environment for the glycation of insulin (Abdel-Wahab et al. 1996, 1997a, O'Harte et al. 1997). This might reflect the fact that glucose is efficiently transported into the $\beta$-cell by GLUT transporters and rapidly metabolized by glucokinase to the particularly potent glycating agent glucose-6-phosphate (Leahy 1990, Flatt 1992, Avigad et al. 1996, Abdel-Wahab et al. 1997a, 

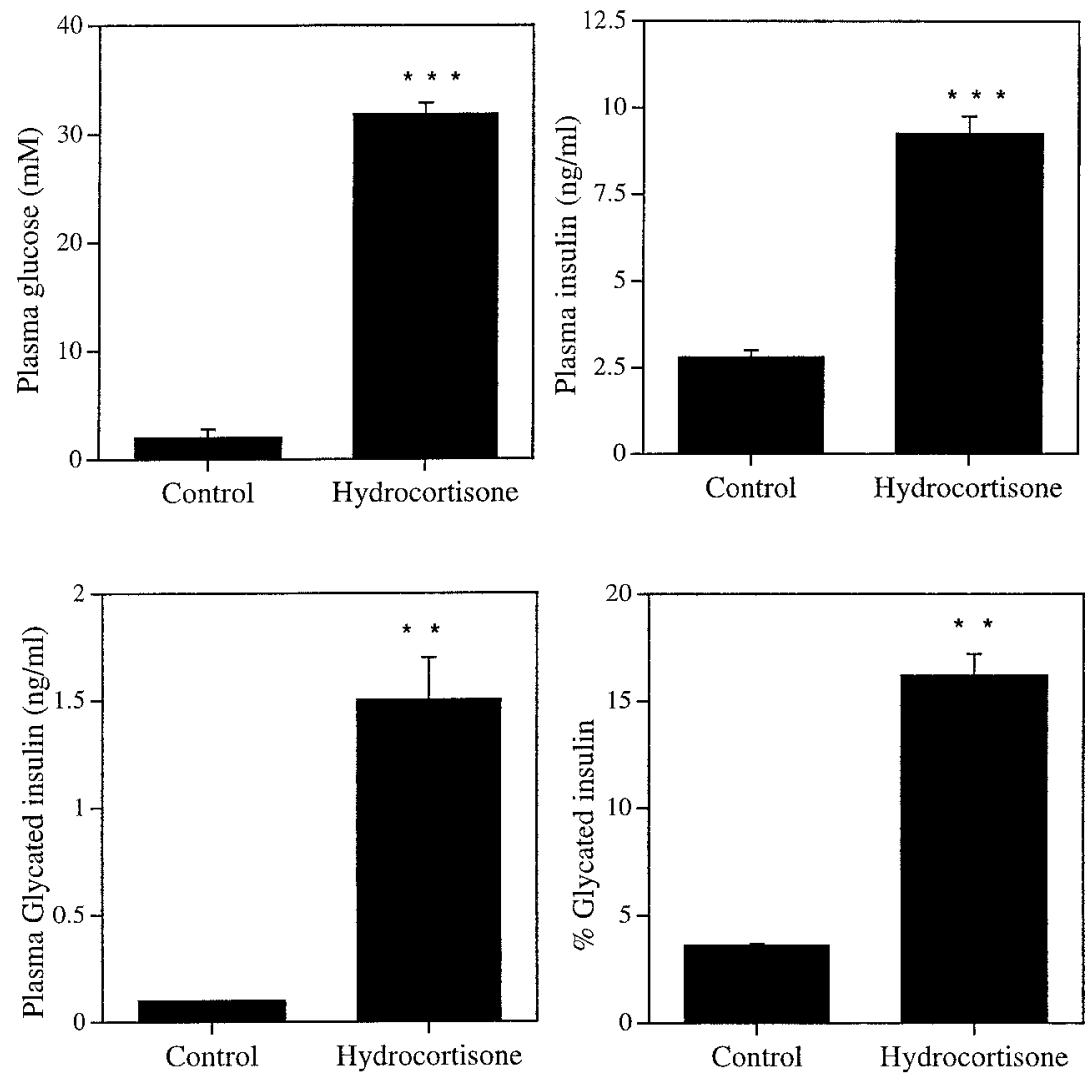

Figure 7 Plasma glucose, insulin, glycated insulin concentrations and percent glycated insulin of control and hydrocortisone-treated rats. Rats received intraperitoneal injections of hydrocortisone $(40 \mathrm{mg} / \mathrm{kg}$ body weight in $0.2 \mathrm{ml}$ corn oil) or corn oil alone (controls) twice daily for a period of 8 days. Glycated insulin was measured by RIA using antiserum from rabbit 3, group 7 (R3/B/GLU/OV/vi). Results are expressed as means \pm S.E.M. for four animals. ${ }^{*} P<0 \cdot 01 ;{ }^{* *} P<0 \cdot 001$, compared with controls.

O'Harte et al. 1997). Since glycated insulin has been shown to exhibit reduced bioactivity and glucoselowering ability (Dolhofer \& Wieland 1979, Lapolla et al. 1988, Hunter et al. 1996, Abdel-Wahab et al. 1997b), an involvement in the glucose toxicity, insulin resistance and glucose intolerance of type 2 diabetes has been postulated (Flatt et al. 1994, 1997).

Observations of glycated insulin have hitherto relied on the rather crude approach of separating glycated and non-glycated proteins by boronate affinity chromatography, followed by the measurement of insulin in both fractions using cross-reacting RIA (Abdel-Wahab et al. 1996, 1997a). With the elucidation of the site of glycation of insulin (i.e. the N-terminal $\mathrm{Phe}^{1}$ of the insulin B-chain; O'Harte et al. 1996), it became possible to envisage development, for the first time, of specific antibodies to the glycated region of the insulin molecule. The present study employed two glycated synthetic peptides for immunogen preparation, representing either the insulin B-chain (1-7) with Tyr at position 8 (peptide A) or the insulin B-chain (1-6) with $\mathrm{Tyr}^{7}$ and $\mathrm{Lys}^{8}$ (peptide B). The rationale for these modifications concerned the use of Tyr for subsequent iodination (Salacinski et al. 1981) and the Lys side chain of peptide B for coupling to carrier protein using glutaraldehyde (Harlow \& Lane 1988).

In all, 10 animal groups were employed; rabbits or guinea-pigs were immunized with glycated peptide $\mathrm{A}$ or $\mathrm{B}$ linked to OV or KLH using either GLU, CDI or MBS. Antisera were evaluated after 8-28 weeks of immunization with mono-iodinated $\mathrm{I}^{125}$-tracer prepared from glycated peptide A, using the solid-phase iodogen method followed by HPLC purification (O'Harte et al. 1996). This analysis revealed that 5 out of the 10 immunized groups developed antibodies against glycated insulin. These included four groups with OV coupled to (i) peptide A using CDI in rabbits (group 2), (ii) peptide B using GLU in guinea-pigs (group 6) or rabbits (group 7), or (iii) peptide B using CDI in guinea-pigs (group 8). However, only one of three animals responded in the latter group, as did only one rabbit in group 10 when immunized with peptide A 

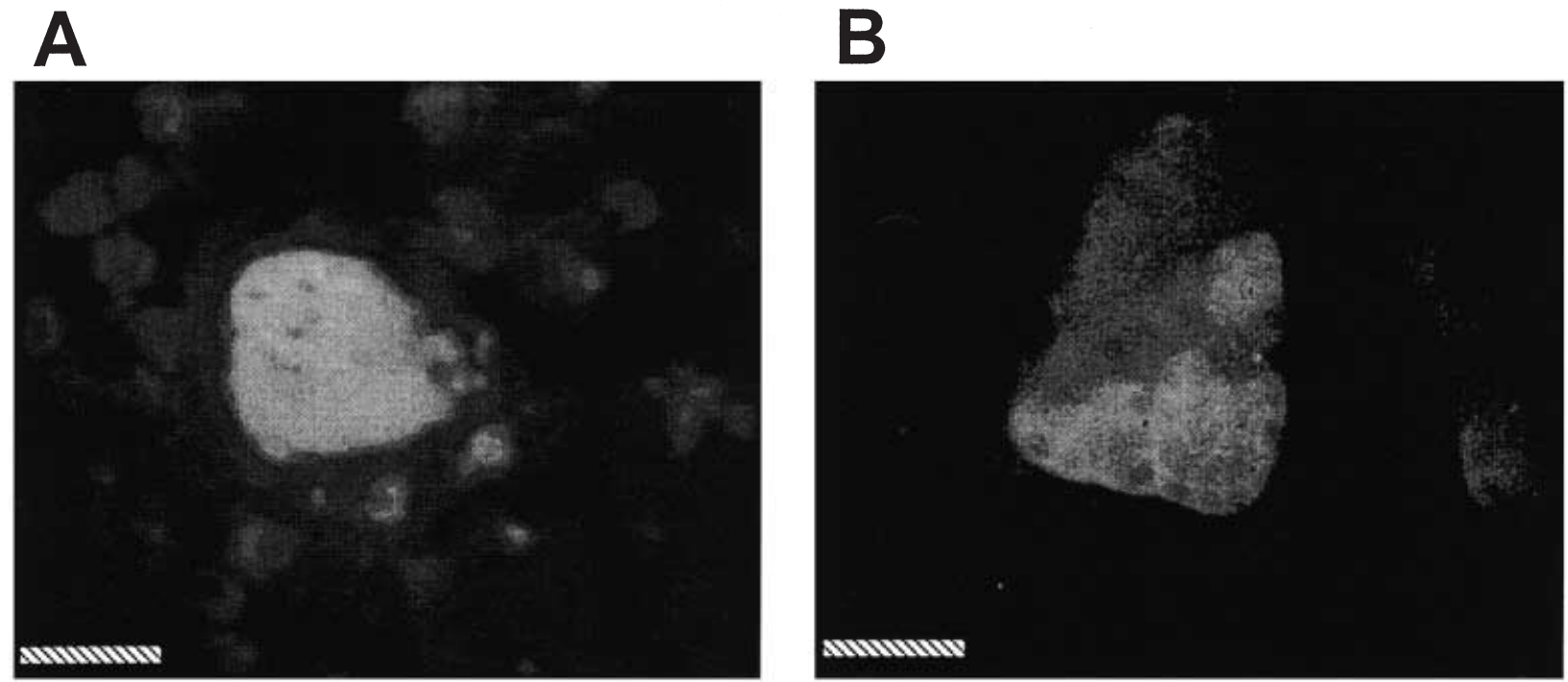

Figure 8 Immunocytochemical demonstration of glycated insulin in pancreatic tissue from (A) a rat with streptozotocin-induced diabetes (plasma glucose $>15 \mathrm{mmol} / \mathrm{l}$ ) and (B) a control rat. Pancreatic tissue sections were immunostained using antisera from guinea-pig 2, group $6(\mathrm{GP} 2 / \mathrm{B} / \mathrm{GLU} / \mathrm{OV} / \mathrm{vi})$, and FITC-labelled secondary antibody. Clusters of fluorescent positively stained islet cells are particularly evident in diabetic tissue (A) surrounded by non-stained exocrine tissue. Scale bar $=100 \mu \mathrm{m}$.

coupled to KLH using GLU. As a general observation, conjugates prepared with peptide A or peptide B using $\mathrm{KLH}, \mathrm{MBS}$ or CDI were either weakly immunogenic or non-immunogenic in guinea-pigs and rabbits.

The highest titre antisera (corresponding to 1:70001:70 000) were observed in guinea-pigs and rabbits receiving peptide B coupled to OV using GLU (groups 6 and 7, respectively). Evaluation by dis-equilibrium RIA revealed complete displacement of the tracer by glycated insulin standards. $\mathrm{ED}_{50}$ values for three guinea-pig antisera (group 6) were $2.5,1.25$ and $0.9 \mathrm{ng} / \mathrm{ml}$, corresponding values of $15,9.6$ and $0.3 \mathrm{ng} / \mathrm{ml}$ being recorded for the three rabbit antisera (group 7). Notably, these antisera exhibited no cross-reaction $(<0 \cdot 001 \%)$ with insulin, proinsulin, Cpeptide, glucagon, somatostatin or AGE-BSA. This suggests that coupling of the glycated insulin fragment to OV through Lys ${ }^{8}$ yielded specific high affinity antibodies to glycated $\mathrm{Phe}^{1}$ and the adjacent $\mathrm{N}$-terminal region of the insulin B-chain.

To check the usefulness of these antisera, the final bleeds of rabbit $3\left(\mathrm{ED}_{50} 0.3 \mathrm{ng} / \mathrm{ml}\right)$ and guinea-pig 2 $\left(\mathrm{ED}_{50} 1.25 \mathrm{ng} / \mathrm{ml}\right)$ were employed for radioimmunoassay and immunocytochemical studies respectively, using two commonly employed animal models of diabetes. Pancreatic tissue from mice with STZ-induced diabetes and hydrocortisone-treated rats have been shown previously (by affinity chromatography and cross-reacting RIA) to contain appreciable amounts of glycated insulin (AbdelWahab et al. 1996). Consistent with these observations, the immunocytochemistry of pancreas resected from rats with STZ-induced diabetes revealed clusters of fluorescent positively stained cells in islets surrounded by non-stained exocrine tissue. Control rats also exhibited numerous positive cells - an observation which is in accord not only with the earlier study (Abdel-Wahab et al. 1996), but also with specific RIA-measured circulating values of $0.08 \mathrm{ng} /$ $\mathrm{ml}$ glycated insulin, estimated at $4 \%$ of total insulin in blood. Glycated insulin in the plasma of hydrocortisonetreated diabetic rats was elevated approximately 19-fold at $1.5 \mathrm{ng} / \mathrm{ml}$, representing approximately $16 \%$ of total circulating insulin in this severely insulin-resistant hyperinsulinaemic animal model.

In conclusion, this paper describes, for the first time, the development and characterization of polyclonal antisera with high specificity and affinity for glycated insulin. RIA and immunocytochemical studies revealed appreciable amounts of glycated insulin in both the pancreas and the circulation of animal models of diabetes. These observations provide the impetus and the means to evaluate the possible involvement of glycated insulin in the glucose toxicity, pancreatic $\beta$-cell dysfunction and insulin resistance of type 2 diabetes.

\section{Acknowledgements}

These studies were supported, in part, by the British Diabetic Association, The Wellcome Trust and University of Ulster Research Strategic Funding. The authors dedicate this paper to Professor W E Watts, Dean of Science, on his retirement. We thank Professor C Shaw and Dr P Harriott for valuable discussions. 


\section{References}

Abdel-Wahab YHA, O'Harte FPM, Ratcliff H, McClenaghan NH, Barnett CR \& Flatt PR 1996 Glycation of insulin in the islets of Langerhans of normal and diabetic animals. Diabetes $\mathbf{4 5}$ 1489-1496.

Abdel-Wahab YHA, O'Harte FPM, Barnett CR \& Flatt PR 1997a Characterization of insulin glycation in insulin-secreting cells maintained in tissue culture. Journal of Endocrinology 152 59-67.

Abdel-Wahab YHA, O'Harte FPM, Boyd AC, Barnett CR \& Flatt PR $1997 b$ Glycation of insulin results in reduced biological activity in mice. Acta Diabetologica 34 265-270.

Avigad G, Kniep A \& Bailin G 1996 Reaction of rabbit skeletal myosin with D-glucose 6-phosphate. Biochemistry and Molecular Biology International 40 273-284.

Blakytny R \& Harding JJ 1992 Glycation (non-enzymic glycosylation) inactivates glutathione reductase. Biochemical Journal 288 303-307.

Boyd AC, O'Harte FPM, Gray AM, Abdel-Wahab YHA, McNulty H, Barnett CR \& Flatt PR 1996 Reduced biological potency of mono-glycated insulin in vitro and in vivo in mice. Diabetologia 39 A23.

Brownlee M 1995 The pathological implications of protein glycation. Clinical Investigations of Medicine 18 275-281.

Brownlee M 2000 Negative consequences of glycation. Metabolism 49 9-13.

Dolhofer R \& Wieland OH 1979 Preparation and biological properties of glycosylated insulin. FEBS Letters 100 133-136.

Flatt PR (Ed) 1992 In Nutrient Regulation of Insulin Secretion. London: Portland Press Ltd.

Flatt PR \& Bailey CJ 1981 Abnormal plasma glucose and insulin reponses in heterozygous lean $(o b /+)$ mice. Diabetologia 20 573-577.

Flatt PR, Abdel-Wahab YHA, Wilson AM, Barnett CR, O'Harte FPM \& Swantson-Flatt SK 1994 Site-specific defects and glucose toxicity in pancreatic $\beta$-cell dysfunction in non-insulin dependent diabetes mellitus. In Frontiers of Insulin Secretion and Pancreatic B-cell Research, pp 481-489. Eds PR Flatt \& S Lenzen. London: Smith-Gordon \& Co. Ltd.

Flatt PR, Abdel-Wahab YHA, Boyd AC, Barnett CR \& O'Harte FPM 1997 Pancreatic B cell dysfunction and glucose toxicity in non-insulindependent diabetes. Proceedings of the Nutrition Society 56 243-262.

Ganea E \& Harding JJ 1994 Inactivation of glucose-6-phosphate dehydrogenase by glycation. Biochemical Society Transactions 22445 S.

Harlow E \& Lane D (Eds) 1988 In Antibodies: a Laboratory Manual. Cold Spring Harbor: Cold Spring Harbor Laboratory Press.
Hunter SJ, Wiggam MI, Boyd AC, O'Harte FPM, Ennis CN, Gamble R, Sheridan B, Barnett CR, McNulty H, Bell PM \& Flatt PR 1996 Glycation of human insulin reduces its biological potency as assessed by euglycaemic clamps in normal man. Diabetic Medicine (Suppl 7) 13 S17-S18.

Lapolla A, Tessari P, Poli T, Valerio A, Duner E, Iori E, Fedele D \& Crepaldi G 1988 Reduced in vivo biological activity of in vitro glycosylated insulin. Diabetes 37 787-791.

Leahy JL 1990 Natural history of B-cell dysfunction in NIDDM. Diabetes Care 13 992-1010.

Lyons TJ \& Jenkins AJ 1997 Glycation, oxidation, and lipoxidation in the development of the complications of diabetes: a carbonyl stress hypothesis. Diabetes Reviews 5 365-391.

Oda A, Bannai C, Yamaoka T, Katori T, Matsushima T \& Yamashita K 1994 Inactivation of $\mathrm{Cu}$, Zn-superoxide dismutase by in vitro glycosylation and in erythrocytes of diabetic patients. Hormone and Metabolic Research 26 1-4.

O'Harte FPM, Højrup P, Barnett CR \& Flatt PR 1996 Identification of the site of glycation of human insulin. Peptides 17 1323-1330.

O'Harte FPM, Penney AC \& Flatt PR 1997 Glycation of insulin by phosphorylated and non-phosphorylated reducing sugars. Biochemical Society Transactions 25 150S.

Perry RE, Swamy MS \& Abraham EC 1987 Progressive changes in lens crystallin glycation and high-molecular-weight aggregate formation leading to cataract development in streptozotocin-diabetic rats. Experimental Eye Research 44 269-282.

Salacinski PRP, McLean C, Sykes JEC, Clement-Jones W \& Lowry PJ 1981 Iodination of proteins, glycoproteins and peptides, using a solid phase oxidising agent: 1,3,4,6-tetrachloro-3a,6adiphenylglycouril (Iodogen) Analytical Biochemistry 117 136-146.

Stevens JF 1971 Determination of glucose by automatic analyzer. Clinica Chimica Acta 32 199-201.

Takahashi M, Lu Y, Myint T, Fujii J, Wada Y \& Taniguchi N 1995 in vivo glycation of aldehyde reductase, a major 3-deoxyglucosone reducing enzyme: identification of glycation sites. Biochemistry 34 $1433-1438$.

Unger RH \& Grundy S 1985 Hyperglycaemia as an inducer as well as a consequence of impaired islet cell function and insulin resistance: implications for the management of diabetes. Diabetologia 28 119-121.

Received 5 May 2000

Accepted 15 June 2000 